G.S. Springer, L.N. Mihindukulasooriya, D.M. White, and H.D. Rowe - Micro-charcoal abundances in stream sediments from Buckeye Creek Cave, West Virginia, USA. Journal of Cave and Karst Studies, v. 74, no. 1, p. 58-64. DOI: 10.4311/2010AN0148R1

\title{
MICRO-CHARCOAL ABUNDANCES IN STREAM SEDIMENTS FROM BUCKEYE CREEK CAVE, WEST VIRGINIA, USA
}

\author{
Gregory S. Springer ${ }^{* *}$, L. Nivanthi Mihindukulasooriya², D. Matthew White², And \\ HAROLD D. ROWE ${ }^{4}$
}

\begin{abstract}
We compare micro-charcoal abundances in laminated cave-stream sediments to the presences of Native Americans and later settlers in the same watershed. Samples were obtained from a core taken from a $2.5 \mathrm{~m}$ high point bar located $1 \mathrm{~km}$ inside of Buckeye Creek Cave, West Virginia. Thirty-three subsamples were treated with hydrogen peroxide to bleach or whiten non-charcoal organic matter. In the absence of opaque mineral grains, this technique creates a large visual contrast between dark charcoal grains and other substances. The subsamples were photographed using a microscope-mounted camera, and pixels darker than 99/255 (grayscale) were used to calculate charcoal concentrations. The record spans the last 6,000 years, and four of the five highest charcoal concentrations are from the last 2,000 years. The highest concentration is from AD 1093, and the second-highest concentration is from the nineteenth century. Post-Colonial settlers began making extensive use of the watershed sometime in the eighteenth century and may, therefore, be responsible for the second-highest charcoal concentration. However, archaeologists independently concluded that Native Americans made peak use of the watershed between AD 1000 and 1200, which coincides with the highest charcoal concentration in the record. Native Americans are known to have extensively used fire, so there is good circumstantial evidence tying high concentrations in the last 2,000 years to human activities. Our method is suitable for use elsewhere, and we present a detailed statistical analysis of our data as a guide toward interpreting charcoal concentrations in karst and non-karst deposits.
\end{abstract}

\section{INTRODUCTION}

Clastic cave sediments preserve records of geomorphic processes, climate, and land uses as fluctuations in geochemistry, mineralogy, or organic matter (Springer, 2005). The latter includes charcoal, the abundance of which is an especially valuable proxy for land use. However, sedimentary-charcoal abundances are little studied in true caves, as opposed to rock shelters. Charcoal abundances are widely measured in lacustrine sediments, and lakebased studies often focus on reconstructing detailed fire histories and identifying peak times of charcoal deposition (Higuera et al., 2007). These have many applications within climate, forest succession, and archaeological studies (Conedera et al., 2009; Théry-Parisot et al., 2010). Conceptually, high charcoal abundances may represent periods of frequent fires or greater fire severities, but mixing and storage during transport through stream networks creates a persistent background signal, while the mechanisms of transport and the distances over which charcoal is transported significantly affect particle size and abundance in sedimentary deposits (Conedera et al., 2009; Higuera et al., 2007). These limitations explain why much attention is given to peaks in charcoal abundance data. Nonetheless, the fluvial processes that effectively filter and smooth charcoal abundances are presumably true of both surface and subsurface streams and charcoal abundances in clastic cave sediments may be valuable for understanding a variety of natural and anthropogenic processes (Carcaillet et al., 2007).

As part of a geoarchaeological study, we sought to efficiently measure a statistically meaningful number of charcoal abundances in clastic cave sediments $(n \geq 30)$ by refining an existing charcoal separation method (Rhodes, 1998). We examined fine-grained sediments containing only micro-charcoal fragments less than $1 \mathrm{~mm}$ in diameter and not readily visible to the unaided eye. After separating or distinguishing charcoal from unconsolidated sediments and other detritus, the necessary data are obtained by counting charcoal grains or measuring charcoal-grain surface areas or volumes (Ali et al., 2009). The separation and quantification procedures can be very time consuming and impacts the number and spacing of samples and their temporal resolution (Rhodes, 1998). These issues can limit

\footnotetext{
* Corresponding Author

${ }^{1}$ Department of Geological Sciences, Ohio University, Athens, OH 45701 springeg@ ohio.edu

${ }^{2}$ Department of Geology, Kent State University, Kent, OH 45701 1nivanthi@, yahoo.com

${ }^{3}$ ExxonMobil, 800 Bell Street, Room 2897D, Houston, TX 77002 david.m.white@ exxonmobil.com

${ }^{4}$ Department of Earth and Environmental Sciences, The University of Texas at Arlington, Arlington, TX 76019 hrowe@uta.edu
} 

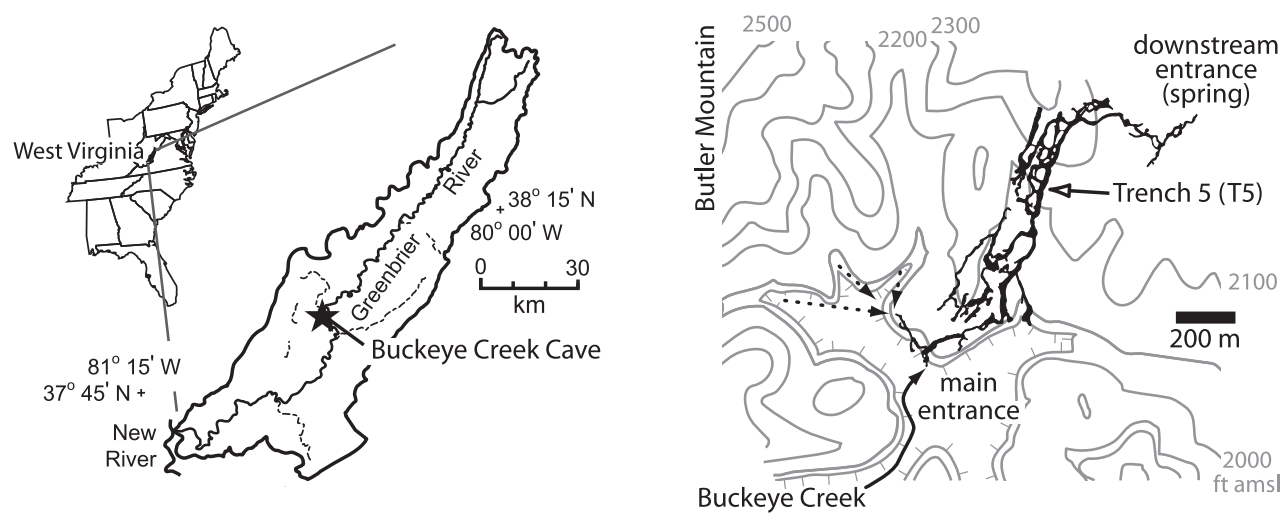

Figure 1. Buckeye Creek is located in southeastern West Virginia (left panel) and enters the cave after flowing across an active floodplain within a large karst depression (right panel). A plan view of the cave is superimposed on basin topography at right, and the location of our sediment trench is indicated. Adapted from Dasher and Balfour (1994) and Springer et al. (2010).

a researcher's ability to distinguish between charcoalabundance values of anthropogenic and non-anthropogenic origins. Therefore, we used digital processing to generate data more efficiently and in sufficient numbers for statistical analysis. We describe our laboratory method and provide statistical analysis of our results. The reliability of the latter is tested by briefly comparing micro-charcoal abundances to independent geological (Springer et al., 2008) and archaeological data (McBride and Sherwood, 2006; Springer et al., 2010). In doing so, we assumed that charcoal abundances reflect some aspect of fire frequencies or severities (Higuera et al., 2007; Conedera et al., 2009; Théry-Parisot et al., 2010), but do not interpret our record as a detailed fire history. Instead, we focus on peak abundances and whether these peaks are correlated with human activities in the source watershed. Our microcharcoal technique should be of value to others and has many potential applications in cave and karst studies.

\section{Study Area}

We report data collected from a point bar deposited by a stream in Buckeye Creek Cave, which drains a topographically enclosed, $14 \mathrm{~km}^{2}$ watershed in southeastern West Virginia, USA (Fig. 1). Buckeye Creek flows through a $2 \mathrm{~km}$ long passage averaging $10 \mathrm{~m}$ wide and $4 \mathrm{~m}$ high (Dasher and Balfour, 1994; Springer, 2004). Silt banks are found on one or both sides of the stream for much of its underground course. The fine-grained sediments are derived from a karst watershed draining Mississippian-age sandstones, siltstones, and shales of Butler Mountain. Surface streams carry siliciclastic detritus to the base of Butler Mountain, where streams sink into their beds or swallet holes in limestonefloored valleys (Springer et al., 2003).

\section{Methods}

We dug a trench in the face of a $2.6 \mathrm{~m}$ high point bar, $1 \mathrm{~km}$ downstream of the cave entrance in a $20 \mathrm{~m}$ wide by
$7 \mathrm{~m}$ high passage. Deposition continues atop the point bar, although the stream has meandered against the bar to create a cutbank. The sediments lack interior scour surfaces, hard-grounds, and other indications of erosion or periods of non-deposition. Therefore, we assume deposition has been essentially continuous since the sediments began accumulating. The sediments were described and sampled in the field, but we also cored the face of the trench by pushing PVC sleeves into the sediments. The sleeves are made from PVC tubes with square cross sections, measuring $10.2 \mathrm{~cm}$ on a side (4 inches square), cut lengthwise to yield a square-cornered trough. Core lengths were typically $\sim 50 \mathrm{~cm}$, and the sleeves overlapped to create a continuous sample of the sediments. The open sides of sleeves were pressed into sediment before being cut out of the trench wall, wrapped in protective materials, and carried out of the cave. This allowed us to perform detailed subsampling and laboratory analyses in a controlled environment.

The cores were sampled at selected depths for charcoal analysis using a method described by Rhodes (1998). Subsamples weighing $2 \mathrm{~g}$ were removed from sediment cores and dried for two days, rehydrated with dilute potassium hydroxide $(\mathrm{KOH})$, decanted, and treated with $20 \mathrm{ml}$ of $5 \%$ hydrogen peroxide $\left(\mathrm{H}_{2} \mathrm{O}_{2}\right)$. The peroxide treatment bleaches all organic matter except charcoal, which remains dark and contrasts markedly with the bleached organics and light-colored and translucent sediment grains. We used the contrast created by the $\mathrm{H}_{2} \mathrm{O}_{2}$ treatment to estimate charcoal concentrations using a digital technique. The prepared samples were placed in petri dishes and photographed using digital photomicroscopy. Individual images were converted to grayscale, and all pixels below a grayscale threshold of 99/255 were counted using ImageJ software (http://rsbweb.nih.gov/ij/) (Fig. 2). The use of pixel-counting greatly speeds estimation of charcoal concentrations, but it over-counts charcoal abundances because some dark objects are probably not charcoal. However, we visually scanned all dishes during 


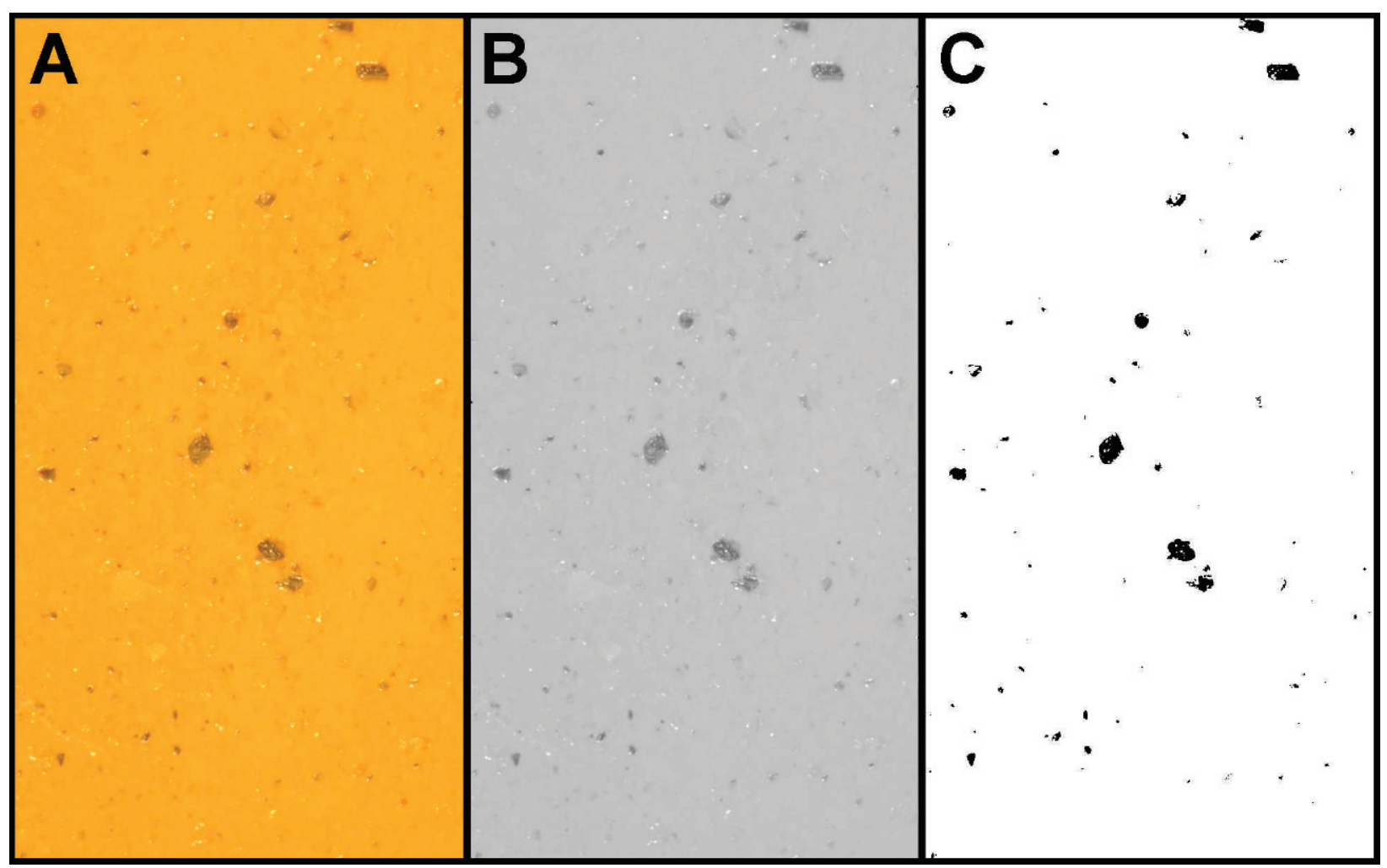

Figure 2. Charcoal concentrations were measured by photographing prepared sediment samples (A), converting the images to grayscale (B), and counting all pixels below a grayscale threshold of 99/255 (C). The darkest pixels were assumed to be charcoal because extensive pretreatment with $\mathrm{H}_{2} \mathrm{O}_{2}$ bleached all other organic matter and no dark mineral grains were observed during photographing.

photomicroscopy and did not observe any dark mineral grains, probably because the silts and sands are greater than $99 \%$ quartz, as measured using X-ray diffraction. However, to control for contamination from dark, noncharcoal particles, we averaged the results of multiple images taken from different areas within individual petri dishes.

\section{Micro-Charcoal Results and Statistics}

A total of 33 samples were analyzed for micro-charcoal concentrations. The first sample was taken $1 \mathrm{~cm}$ below the top of the deposit (core), and additional samples were taken every $2 \mathrm{~cm}$ to a depth of $27 \mathrm{~cm}$ (total $n=14$ ). Thereafter, samples were collected every 3 to $4 \mathrm{~cm}$ to a depth of $98 \mathrm{~cm}(n=19)$. Ages were assigned to each sample using an age-depth model built from seven radiocarbon dates. The model and its uncertainties are discussed in Springer et al. (2010), and the basal sediments are $\sim 6,500$ years old. Charcoal concentrations range over an order of magnitude ( 0.22 to $2.15 \mathrm{~mm}^{2} \mathrm{~cm}^{-2}$ ). Overall, values are highest in the late Holocene, but there is considerable variability during this time (Fig. 3). Overall, concentrations are strongly skewed to the left and failed a Shapiro-Wilk test for normality $(p=0.007)$. Using the same test and a base-ten log transformation, the values are lognormally distributed ( $p=0.995)$ and their cumulative frequencies fall on a nearly straight line when plotted using a probability scale (Fig. 4). Nonetheless, the lowest and five highest points do not fall on the line. Following the methods of Sinclair (1974) and Reimann et al. (2005), we did not perform outlier tests, but calculated thresholds above which data points are anomalous and deserving further analysis.

Threshold values can be chosen in a variety of ways. Conventional methods include using the value corresponding to the mean \pm 2 standard deviations (mean $\pm 2 \mathrm{sdev}$ ), median \pm 2 median absolute deviation (MAD), and the box-plot method (Reimann et al., 2005). According to mean \pm 2 sdev method, values outside upper and lower thresholds are considered possible outliers worthy of further attention. However, this method identifies only $5 \%$ of actual extreme values (Reimann et al., 2005), and in our case, is exceeded only by the AD 1093 value (Fig. 4). The box-plot method was performed using Systat's SigmaPlot and identified the AD 1889, AD 1093, and AD 24 values as outliers (Fig. 4 inset). The MAD method usually resulted in a lower threshold level than the box-plot or mean \pm 2 sdev methods, and its threshold was lower than the four largest charcoal concentrations (Fig. 4). 

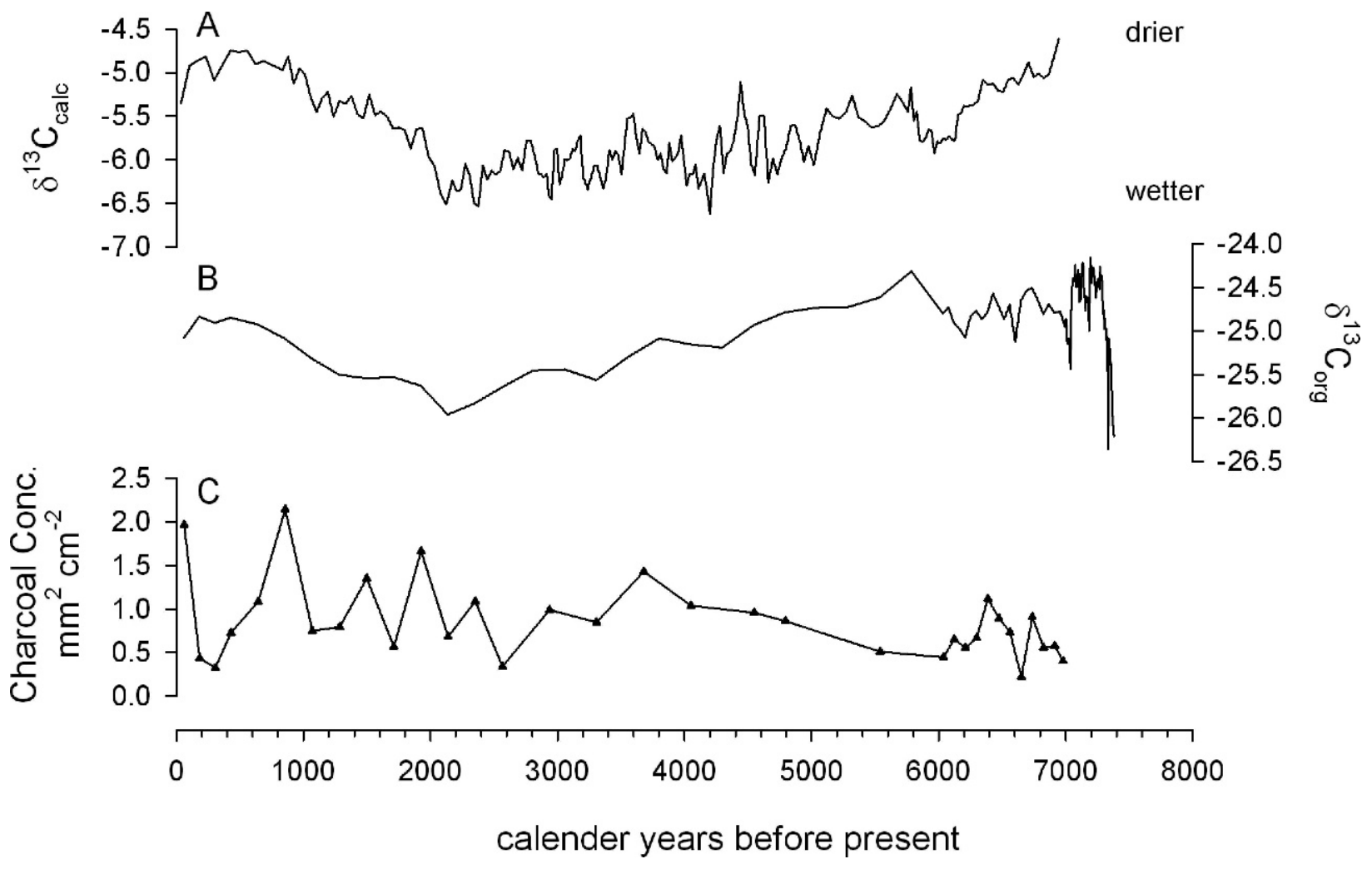

Figure 3. (A) A stable isotopic $\left({ }^{13} \mathrm{C}_{\text {calc }}\right)$ paleoclimatic record obtained from a stalagmite records long-term changes in the soils and ecosystem above Buckeye Creek Cave (Springer et al., 2008). Moisture levels increased from the mid to late Holocene, but ${ }^{13} \mathrm{C}_{\text {calc }}$ values increased abruptly $\sim 100 \mathrm{BC}$ This coincides with use of Unnamed Cave \#14 (UC14) by Native Americans, and values peak approximately when Native Americans were making their most extensive use of UC14 (Maslowski, 2006). Other regional paleoclimatic records do not record drying after 2,100 years BP (Springer et al., 2009; 2010), but the anomalous ${ }^{13} \mathrm{C}_{\text {calc }}$ record is corroborated by stable isotopic analysis of organic material $\left({ }^{13} \mathrm{C}_{\text {org }}\right)$ in the Trench Five sediments (B). (C) Fire activity was high during the Late Holocene and peaks near the times of peak ${ }^{13} \mathrm{C}_{\text {calc }}$ and ${ }^{13} \mathrm{C}_{\text {org }}$ values, coinciding with peak Native American use of the watershed, as inferred from the UC14 record (McBride and Sherwood, 2006).

However, these methods do not take into account the possibility that the anomalous values are derived from a different population than the background population of points falling on an approximately straight line in Figure 4. If two populations have been sampled, the mean and standard deviation of the pooled data may not be statistically meaningful. As a consequence, the strict application of threshold values yields questionable results (cf. Reimann et al., 2005).

There are alternatives to using thresholds of purely quantitative derivation. Among these, the most popular remains subjective interpretation of non-linearity in cumulative probability plots, whereby the point of maximum curvature is interpreted as the threshold separating different populations (Sinclair, 1974; Reimann et al., 2005). Points beyond the curvature threshold should be subjected to additional investigation, because Monte Carlo simulations indicate this method yields too many outliers (Reimann et al., 2005). When plotted as cumulative probabilities (Fig. 4), the five highest concentrations do not fall on a trend line drawn through intermediate charcoal concentration values and five samples qualify as being anomalous: AD 1889, AD 1093, AD 452, AD 24, and $1730 \mathrm{BC}$.

\section{Discussion}

The last 2,000 years includes four of the five highest micro-charcoal concentrations and all statistical methods identified the AD 1093 event as an anomalous value. The charcoal is derived from a very small watershed $\left(14 \mathrm{~km}^{2}\right)$, which is ideal because large watersheds allow too much particle mixing and smoothing of peak fire events (Carcaillet et al., 2007). Variability in locally generated charcoal deposits usually reflects an event-dominated record, with major fire episodes recorded as spikes in charcoal abundances (Clark et al., 1996; Marlon et al., 2006; Carcaillet et al., 2007). Alternatively, variability can reflect one or more flaws in sampling or measurement methodologies. On this matter, we note that White (2007) contains a lower resolution micro-charcoal record made using the same techniques. His record also shows high late 


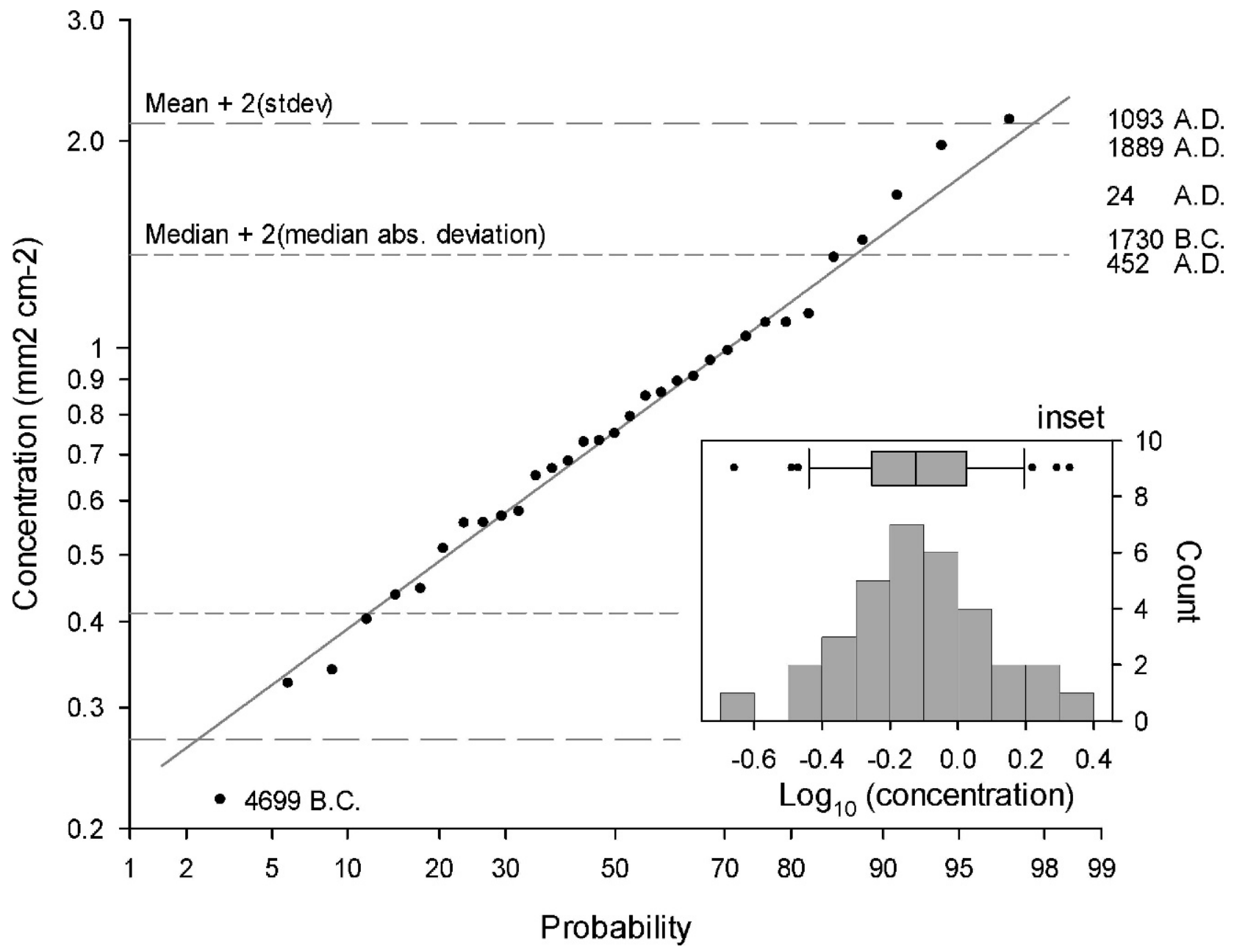

Figure 4. Charcoal concentrations display a log-normal distribution (inset). The cumulative distribution function of charcoal concentrations is plotted, and five anomalously high concentrations are labeled. Thresholds calculated to identify anomalous values are shown as dashed lines and within the box plot (inset) as black circles. Details discussed in the text.

Holocene charcoal abundances relative to mid-Holocene values. Nonetheless, the highest concentrations are above several thresholds (Fig. 4) and, therefore, worth additional consideration. So, we compare their timings to an independent archaeological investigation conducted in Unnamed Cave \#14 (UC14) adjacent to Buckeye Creek Cave (Fig. 5). (The common name and entrance location of UC14 are on file with the State of West Virginia Division of Culture and History, but are withheld to protect enclosed cultural remains.) The comparison is a test of whether humans could be responsible for the high charcoal concentrations.

UC14 consists of a $30 \mathrm{~m}$ by $46 \mathrm{~m}$ entrance room and more than $100 \mathrm{~m}$ of interior passages. The entrance room is more than $3 \mathrm{~m}$ high and hospitable for human habitation, with a flat floor and daytime illumination from a southeast-facing entrance. Drs. Kim McBride and Sarah Sherwood of the Kentucky Archaeological Survey and Dickinson College in Pennsylvania, respectively, led the project and co-edited a volume composed of chapters dedicated to stone implements and debitage, pottery sherds, petroglyphs, hearths, and foodstuffs (McBride and Sherwood, 2006). The report is on file with the West Virginia Cave Conservancy (http://www.wvcc.net/).

Cultural remains were assigned ages by comparing their morphologies to published, well-dated cultural materials from other regional excavations (Fig. 5) (Maslowski, 2006; McBride, 2006; Simek and Cressler, 2006). Collectively, the cultural remains reveal that UC14 was utilized in one or more ways from the Late Archaic through the Late Prehistoric $(5,000$ to 250 calendar years BP), at least occasionally. The three most culturally distinctive artifact classes are projectile points, pottery, and petroglyphs. All three types of remains are represented between AD 1000 and 1200 (750 and 550 years BP; black in Fig. 5). Maslowski (2006) inferred that peak Native American utilization of UC14 occurred during that time period. This is circumstantial evidence that Native Americans are responsible for fires that produced several of the highest charcoal concentrations. 


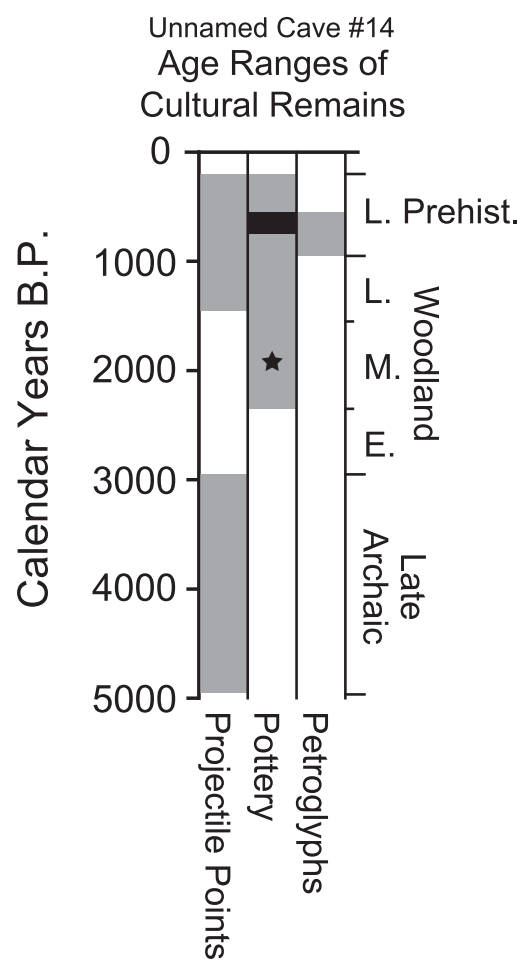

Figure 5. The gray regions represent cultural ages assigned to projectile points (McBride, 2006), pottery (Maslowski, 2006), and petroglyphs (Simek and Cressler, 2006) found in Unnamed Cave \#14. The black bar in the pottery column denotes the age range of distinctive Page Cord ceramics (Maslowski, 2006). The black star is a radiocarbon date obtained from pottery fragments (McBride and Sherwood, 2006).

However, the second highest value is found at $1 \mathrm{~cm}$ depth in Trench Five. The corresponding date, AD 1889, is after Europeans began making substantial changes to Greenbrier County ecosystems (Hale, 1886). Knowing that settlers and their descendants performed extensive land clearance (Hale, 1886), it seems highly probable that the second-highest peak reflects human activities. A fifth point, $1730 \mathrm{BC}$, also lies above the trend line, but only a few Archaic artifacts were found in $\mathrm{UC14}$, and the significance of the high micro-charcoal abundance value is unclear.

\section{Conclusions}

Four of the five highest micro-charcoal abundances in Buckeye Creek Cave sediments were generated at times when humans were making significant use of the Buckeye Creek watershed. Native Americans are known to have managed forests using fire, and subsequent settlers used fire to clear land, so there is strong circumstantial evidence that humans are responsible for high charcoal concentrations created during the late Holocene (Springer et al., 2010). Archaeological studies often make use of clastic sediments in rock shelters (Springer, 2005), but cave interior deposits are rarely used as we have done. Microcharcoal may represent a valuable resource because it accumulates in laminated sediments with simple origins, and very small samples are sufficient for analysis. Noncave records may be unavailable in many settings, so agreement between our micro-charcoal results and human activities give confidence that micro-charcoal in cave sediments can be useful for reconstructing land uses and ecological regimes. We recommend micro-charcoal data be subjected to statistical analysis, because high concentrations are not uniquely associated with any particular source (Conedera et al., 2009). We also believe threshold-based approaches used in geochemical studies are appropriate for micro-charcoal studies (Sinclair, 1974; Reimann et al., 2005), but recommend generating as many data points as is practical.

\section{REFERENCES}

Ali, A.A., Higuera, P.E., Bergeron, Y., and Carcaillet, C., 2009, Comparing fire-history interpretations based on area, number and estimated volume of macroscopic charcoal in lake sediments: Quaternary Research, v. 72, no. 3, p. 462-468. doi: 10.1016/j.yqres. 2009.07.002.

Carcaillet, C., Perroux, A., Genries, A., and Perrette, Y., 2007, Sedimentary charcoal pattern in a karstic underground lake, Vercors massif, French Alps: implications for palaeo-fire history: The Holocene, v. 17, no. 6, p. 845-850. doi: 10.1177/0959683607080524.

Clark, J., Royall, P., and Chumbley, C., 1996, The role of fire during climate change in an eastern deciduous forest at Devil's Bathtub, New York: Ecology, v. 77, no. 7, p. 2148-2166. doi: 10.2307/2265709.

Conedera, M., Tinner, W., Neff, C., Meurer, M., Dickens, A.F., and Krebs, P., 2009, Reconstructing past fire regimes: methods, applications, and relevance to fire management and conservation: Quaternary Science Reviews, v. 28, no. 5-6, p. 555-576. doi: 10.1016/j.quascirev. 2008.11.005.

Dasher, G., and Balfour, W., eds., 1994, The Caves and Karst of the Buckeye Creek Basin: Barracksville, West Virginia, West Virginia Speleological Survey bulletin 12, $326 \mathrm{p}$.

Hale, J., 1886, Trans-Allegheny Pioneers: Historical Sketches of the First White Settlements West of the Alleghenies 1748 and After: Cincinnati, Ohio, Graphic Press, 330 p.

Higuera, P.E., Peters, M.E., Brubaker, L.B., and Gavin, D.G., 2007, Understanding the origin and analysis of sediment-charcoal records with a simulation model: Quaternary Science Reviews, v. 26, no. 1314, p. 1790-1809. doi: 10.1016/j.quascirev.2007.03.010

Marlon, J., Bartlein, P.J., and Whitlock, C., 2006, Fire-fuel-climate linkages in the northwestern USA during the Holocene: The Holocene, v. 16, no. 8, p. 1059-1071. doi: 10.1177/0959683606069396.

Maslowski, R., 2006, Ceramic analysis, in McBride, K., and Sherwood, S., eds., Report of Archaeological Investigations at [Unnamed Cave \#14], West Virginia: Lexington, Kentucky, Kentucky Archaeological Survey, p. 7.1-7.10.

McBride, J., 2006, Analysis of stone tools, in McBride, K., and Sherwood, S., eds., Report of Archaeological Investigations at [Unnamed Cave \#14], West Virginia: Lexington, Kentucky, Kentucky Archaeological Survey, p. 8.1-8.9.

McBride, K., and Sherwood, S., eds., 2006, Report of Archaeological Investigations at [Unnamed Cave \#14], West Virginia: Lexington, Kentucky, Kentucky Archaeological Survey.

Reimann, C., Filzmoser, P., and Garrett, R.G., 2005, Background and threshold: critical comparison of methods of determination: Science of The Total Environment, v. 346, no. 1-3, p. 1-16. doi: 10.1016/j.scitotenv. 2004.11.023.

Rhodes, A.N., 1998, A method for the preparation and quantification of microscopic charcoal from terrestrial and lacustrine sediment cores: The Holocene, v. 8, no. 1, p. 113-117. doi: 110.1177/095968369800800114. 
Simek, J., and Cressler, A., 2006, Prehistoric cave art in [Unnamed Cave \#14], West Virginia, in McBride, K., and Sherwood, S., eds., Report of Archaeological Investigations at [Unnamed Cave \#14], West Virginia: Lexington, Kentucky, Kentucky Archaeological Survey, p. 3.1-3.13.

Sinclair, A., 1974, Selection of threshold values in geochemical data using probability graphs: Journal of Geochemical Exploration, v. 3, no. 2, p. 129-149. doi: 10.1016/0375-6742(74)90030-2.

Springer, G.S., 2004, A pipe-based, first approach to modeling closed conduit flow in caves: Journal of Hydrology, v. 289, no. 1-4, p. 178-189. doi: 10.1016/j.jhydrol.2003.11.020.

Springer, G.S., 2005, Clastic sediments in caves, in Culver, D., and White, W., eds., Encyclopedia of Caves: Amsterdam, Boston, Academic Press, p. 102-108.

Springer, G., Rowe, H., Hardt, B., Edwards, R.L., and Cheng, H., 2008, Solar forcing of Holocene droughts in a stalagmite record from West Virginia in east-central North America: Geophysical Research Letters, v. 35, L17703 p. doi: 10.1029/2008GL034971.

Springer, G.S., Rowe, H., Hardt, B., Cocina, F.G., Edwards, R.L., and Cheng, H., 2009, Climate driven changes in river channel morphology and base level during the Holocene and Late Pleistocene of
Southeastern West Virginia: Journal of Cave and Karst Studies, v. 71 , no. 2 , p. 121-129.

Springer, G.S., White, D.M., Rowe, H.D., Hardt, B., Mihindukulasooriya, L.N., Cheng, H., and Edwards, R.L., 2010, Multiproxy evidence from caves of Native Americans altering the overlying landscape during the late Holocene of east-central North America: The Holocene, v. 20, no. 2, p. 275-283. doi: 10.1177/0959683609350395.

Springer, G.S., Wohl, E.E., Foster, J.A., and Boyer, D.G., 2003, Testing for reach-scale adjustments of hydraulic variables to soluble and insoluble strata: Buckeye Creek and Greenbrier River, West Virginia: Geomorphology, v. 56, no. 1-2, p. 201-217. doi: 10.1016/S0169555X(03)00079-5.

Théry-Parisot, I., Chabal, L., and Chrzavzez, J., 2010, Anthracology and taphonomy, from wood gathering to charcoal analysis. A review of the taphonomic processes modifying charcoal assemblages, in archaeological contexts: Palaeogeography, Palaeoclimatology, Palaeoecology, v. 291, no. 1-2, p. 142-153. doi: 10.1016/j.palaeo.2009. 09.016 .

White, D.M., 2007, Reconstruction and Analysis of Native American land use during the late Holocene [M.S. Thesis]: Athens, Ohio, Ohio University. 164 p. 